\title{
Co-evolution of Forestry Policy Development and System-Social Community
}

\author{
Marwoto $^{1, *}$, Hariadi Kartodihardjo ${ }^{2}$, Dudung Darusman ${ }^{2}$, Soeryo Adiwibowo ${ }^{3}$ \\ ${ }^{1}$ Faculty of Forestry, Jambi University, Indonesia \\ ${ }^{2}$ Faculty of Forestry, Bogor Agricultural University, Indonesia \\ ${ }^{3}$ Faculty of Human Ecology, Bogor Agricultural University, Indonesia
}

Copyright $\subseteq 2017$ by authors, all rights reserved. Authors agree that this article remains permanently open access under the terms of the Creative Commons Attribution License 4.0 International License

\begin{abstract}
Developing forests is synonymous with building communities around the forest. Forest destruction is related to the behavior of people living around the forest. Society will always adjust its life to the changes that occur around it in the process of adaptation to be able to live its life. The study found that the failure of forest management was caused by the failure of the process of adaptation of forest management policies with local communities' practice traditions and social systems. Forestry development policy often leads to exclusion of the state to the already living and resident communities in the areas established by the development of the forestry sector. This fact raises the issue of conflict of interest between the surrounding community and the forest manager. On the basis of the findings of this study I suggest; To prevent degradation and deforestation, a new paradigm of forest management systems is required which retains the ecological, economic and socio-cultural functions of local communities as subjects and uses local knowledge and culture as the basis for their governance, and involves other sector commodities to increase their economic value (incentives).
\end{abstract}

Keywords Co-evolution, Forest Development, Social System, Institutional

\section{Introduction}

Forests and forest communities are inseparable entities. People have settled and lived in the forest long before the State itself existed. For forest communities, forests are the source of life in which all the necessities of life are obtained from the forest. This dependence and inseparability between the management of resources and biodiversity with local social systems living in the community can be explicitly seen in everyday life in rural areas, both in indigenous communities and in other local communities still Implementing part of the social system based on traditional knowledge and ways of life.

Protecting forests does not mean just getting rid of local people. But simple solutions rarely exist. When the use of forest resources is limited, there must be an alternative source of income for people who depend on forest resources [41]. Protecting forests does not mean just getting rid of local people. But simple solutions rarely exist. When the use of forest resources is limited, there must be an alternative source of income for people who depend on forest resources [41].

Those who are traditionally dependent and have a strong socio-cultural and religious ties with their local environment, communities that live on the basis of their hereditary origins over a territory that has sovereignty over land and natural wealth, regulated social and cultural life by customary law and adat institutions that manage the survival of society.

There have been numerous studies showing that indigenous peoples in Indonesia have traditionally managed to preserve and enrich natural biodiversity [16]. It is a reality that most indigenous peoples still have local wisdom in the management of natural resources. These local systems differ from one another to the socio-cultural conditions and types of local ecosystems. They generally have a system of knowledge and management of local resources inherited and continually developed for generations. Local institutions that ensure these local systems work effectively [1]. Based on reference [18], the search for policy instruments based on knowledge of cultural aspects, normative behavior or peasant identity conception is a sustainable way to improve landscape quality rather than using payment instruments. Conserving natural resources by imitating the traditional management of anthropogenic habitats is a paradigm in developed countries [20].

Resolving conflicts between the conservation of natural resources and people's livelihood systems attracted the 
attention of many as they have the potential to degrade forest quality. According to the concept of forest conservation should increase the efficiency of agriculture communities around the forest in order to achieve trade-off between agriculture and the extraction of forest products [44].

Indigenous traditional knowledge known as local knowledge or indigenous knowledge has not been widely tested by academics, as it is considered unscientific, subjective and local. In the forestry sector, knowledge of forest science is largely influenced by political and economic power, rather than knowledge of the subsistence nature of Forestry and the support of power from the Ministry of Forestry is more dominant than the institutional strength of society [45].

Local communities in the villages that no longer define and call themselves indigenous peoples, also continuously apply this traditional knowledge (wisdom and knowledge) in their lives, including in utilizing resources and biodiversity to meet their needs such as medicine, food supply and $[3,60]$.

The management of natural resources in Indonesia today is a diverse story. Across millions of hectares, local communities plant forests with fruits, resin, coffee and cocoa and are often planted together with timber trees forming a region called agroforestry [2]. This agro-forestry area provides the same environmental services as natural forests, with the exception of even lower biodiversity differences that many local people are protecting natural forests independently without government interference.

As with other developing countries, the Indonesian government continues to struggle to improve the management of forest resources whose capacity continues to decline. Despite these government efforts, Indonesia still faces real problems with primary and secondary forest ecosystems that are under tremendous threat by both industry and local communities.

The function and role of forests in global environmental change has been the concern of governments, communities and scientists, it can be seen from various studies that prove that forest exploitation in the tropics is unsustainable and that some cases of deforestation can be linked to a permanent conversion process For other uses, such as plantations and agriculture [48,50]. Uncontrolled deforestation will lead to significant externalities with loss of biodiversity, increased risks of erosion, flooding, water scarcity, carbon emissions and global climate change [7]. The immediate impacts of deforestation are the decline in forest users' welfare, loss of certain species, changing local and watersheds, eliminating sources of fuel (wood), fodder and food sources.

The debate over the causes of deforestation between forest managers, policymakers and academics suggests that deforestation is caused by; Population growth [51], population density [26], prosperity [46,50], technology
[46], national debt [23] and commercial logging [35]. This disagreement occurs because there is a difference between concept and operation or there is a knowledge gap in understanding the causes of deforestation [7].

The notion that population growth is a major cause of deforestation [22] by showing that there is a linear relationship between population pressures and degraded land, but in other studies different places indicate that degraded soils occur both in areas of decline and population increase, evidence This shows that there is no relationship between population growth and deforestation $[25,43]$ or it can be argued that strong empirical evidence of the impact of population pressures on deforestation is virtually nonexistent [40]. A study in Kenya indicates that the increase in population means an increase in the availability of labor, if it is harmonized with market opportunities, knowledge, technology and the establishment of institutional structures and the availability of natural resources, a sustainable management pattern will occur [39].

Understanding of local people's lives both on local culture and institutions needs to be done as it will determine success in natural resource management schemes. The debate over deforestation often fails in avoiding deforestation itself due to macro-analysis and failing to understand the social and economic factors that control relationships between people and their environment [12-38-37].

Research is not only limited to the relationship between variables but also see the actual phenomenon or real reality without the limitations of views [13]. Qualitative research can provide many ways to see, interpret and interpret a phenomenon that actually occurs in the environment around humans, such as by using a grounded theory approach [58].

Research with a grounded theory approach is intended to create specifications on: 1) the condition causing the occurrence of a phenomenon, 2) the action or interaction that is the response to the condition, and 3) the consequences arising from such action or interaction. Thus the theoretical formula which is the final result found in qualitative research with grounded theory approach does not justify its applicability to all populations but is only used for such situations or conditions. The form of this research is prescriptive, so it can describe in depth about a social phenomenon at the present moment based on the facts as it then formulate the problem according to the existing circumstances/facts with the aim to get advice on what should be done to overcome the problem [54].

The role of local people becomes important when in their communities have their own rules governing how they interact with their environment and often they ignore the rules made by the state. The community is part of the forest that lives from the forest as a forest product user so that it 
will affect the condition of the forest to alert the researchers and policymakers that including them in the management scheme of forest and environment becomes very important [28]. To understand the interaction between local communities and forests and the environment can be done by identifying the relationship between forest conditions, individuals and institutions they build. Understanding of local institutions as incentives, initiatives and behavioral controls can guide the relationship between forest users and forest conditions [31].

\section{Materials and Methods}

\subsection{Theoretical Framework}

In the concept of co-evolution [49] inspired from Darwin's biological evolutionary concept. In the biological evolution of the existence of the present living being is determined by heredity factors, variations and selection. In social studies the heredity factors are associated with individual karaketristik, the habit that is genetic; Variations are determined by the biophysical type, geographical location, resource availability and selection are associated as a technological influence and market structure $[49,17]$.

To integrate the Jungle rubber in forestry development, I use the concept of policy co-evolution and social systems. The concept I use refers to the process of species domestication in biological terms [49]. The species dominance in biology aims to alter the characteristics or behavior of species to suit human desire. Domestication in this study refers to social science so that social systems in the community can be integrated with conservation ecological system through incentive and policy instruments.

Co-evolution of social policies and systems is the basis for formulating development policies [50]. Changes that occur in people's lives are basically a change from the social system. Social-system changes are a consequence of changes influenced by demographic, economic and technological factors [29]. Social-system changes have a tendency to alter ecosystems, these changes occur in the context of human adaptation to the influence of the surrounding environment $[29,48]$.

Development policy has implications for changes in both biotic and abiotic ecosystem components [50]. Development will affect the human culture associated with its social system as a biotic component of the environment. The dynamics of social-system change in society as a response to ecosystem changes caused by environmental management policies, especially in forestry development, are the focus of the study in this section and an elaboration of the results of the previous chapter.

To minimize the negative impacts of forestry development, it is necessary an institution that can integrate local institutions (social systems) with formal institutions (forestry development policies). The concept of integration is directed to provide economic added value to the community and ensure the sustainability of forest management by the government while still accommodating the local culture associated with its core culture. The concept of a forestry development policy that contains community and government interactions in co-evolution is built on the following [50]: 1) how outsiders favored the ecosystem change; 2) the existence of new knowledge related to the ecosystem; 3) support / influence originating from other regions; 4) the division of authority.

\subsection{Methods}

The research was conducted at The Great Forest Park Sultan Thaha Syaifuddin (Hereafter I call as GFP STS or Tahura STS in Indonesian language) Bungku Village, Pompa Air Village and Singkawang Village, Batanghari District Jambi Province conducted from July 2016 until November 2016. The study aims to understand and explain the role of social systems and community institutions in relation With forests in the midst of development dynamics and market economy. That understanding comes from the search for meanings of the actual experience of society itself. This research is not intended to test the theory, but uses it to help explain the research findings.

The thinking flow of this research is based on the concept of co-evolution [49]. Successful development of forest conservation depends not only on the existence of policy but rather on the policy paradigm that is feasible with the local culture. Integration of forest management is likely to be able to implement sustainable conservation policies.

The philosophical paradigm of this research is social constructivism that develops subjective meanings of informant experience, seeks and focuses on the complexity of the informant's outlook [32]. The strategy of this study is qualitative by exploring and understanding the meaning that by individuals or groups of individuals ascribed to social or humanitarian problems, this research is inductive, focusing on the individual meaning and translating the complexity of a problem and the final conclusion of having a flexible structure [32]. The way used in this research is grounded theory, research departs from general theory and abstraction of a particular process, action or interaction that comes from the views of participants.

The grounded theory method is a systematic generation of theories of data containing inductive and deductive thinking. The principle of research using grounded theory method is not actually inductive or deductive, but by combining inductive and deductive. According to this leads to a research practice where data sampling, data analysis and theoretical development are not seen as distinct and separate, but as different steps have to be repeated to illustrate and explain the phenomenon under study [4]. What distinguishes most grounded theory from many other qualitative research methods is that it explicitly emerges, 
where the grounded theory method does not test the hypothesis, but sets out to find the theoretical theory for such a research situation. In this case it is like a research action that aims to understand the research situation and ultimately to find the implicit theory in the data [4].

The grounded theory approach is a common methodology of analysis associated with systematic data collection applied and uses a series of methods to generate an inductive theory of substantive areas [6]. So it can be said that the implementation of qualitative research with grounded theory method is contrary to quantitative research in general, which originated from conceptual theory to empirical study, whereas grounded theory stems from empirical study based on data obtained toward conceptual theory.

\section{Results and Discussion}

\subsection{Certainty of Land Ownership by the Community}

Tenure of forest land by communities in and around the forest is a very important factor to be studied because there is a historical relationship of forest land tenure that has been done in managing natural resources. Communities around the forest have long lived with the rules, values and norms that prevailed for generations, this has strengthened the rights to natural resources recognized by the community. Currently the focus on rights alone will not guarantee the certainty of forest tenure, as not all rights owned by the community guarantee access to the benefits of the forest resources, and on the contrary there are those who have no rights but have strong access to forest resources [24]. In a conversation I had with Mr. Zein, said;

"I am listed as the first Bungku Village Head. I understand the dynamics of this area of the village including the territories included in the state claim that the GFP area is made. The dynamics of the life of the people of this village I also understand very well. After the HPH concession company closed the community, the job became farmers, especially farming with Rubber gardening. At the beginning of this village the most preferred commodity is Rubber. Our survival depends on the sap from our garden. At the time of high rubber prices people desire to open the garden is very large. At that time the community was free to make a garden by clearing the forest in our village walayah, there was no problem at that time, but after GFP we became no longer free to open the forest for gardening and even prohibited by the government. The area of our village is currently almost $60 \%$ to GFP STS. The gardens that we have and have produced and are in the GFP area we can not harvest sap as before. We are like thieves if we want to take sap from our garden. The problem is that in the community where all the gardens are inside the GFP area, they are severely disadvantaged because to meet the necessities of living to rely on the produce of the garden, while they are not free to harvest and take care of the garden for high production. Currently they can not sell the garden because it is legally not his. There is a habit of poor people here if they want to send their children to sell the garden to finance it ".

Certainty of land satisfaction, is an important thing used to take into account future values in current decision making, it is important related to the benefits gained from the land over time. Reference [9], describes the life of forest villagers as non-static, either voluntarily or compelled to adapt to socioeconomic changes both caused by internal factors (e.g. population growth resulting from birth and death) as well as external factors (E.g. market penetration).

The community has its own mechanism in managing natural resources to be able to meet the needs of his life. This mechanism regulates inter-community relationships in the utilization of natural resources better known as social capital, but today the capacity of social capital is not recognized by the government [16]. The community's natural resources management system is maintained and obeyed by the community but is poorly appreciated and noticed by the government, this can be seen by the decreasing of local people's access to the use of forest and land resources or in other words the government fails to respond to the environmental changes occurring in the community.

The low government response in addressing environmental changes can be seen from the lack of appreciation of the Para Rimbo (Jungle rubber) cultivation that has been proven to be economically able to increase the income of the community and ecologically able to maintain the function. The practice of forest resource management is considered to be less hopeful for the community, including and is expected to provide sustainable, productive, equitable and efficient benefits, but in reality leads to various ecological, economic and socio-cultural conditions that create social inequality, political economy and poverty. On the other hand community forest resource management practices, even under socio-political pressure, persist and demonstrate the ability to realize the sustainability of forest resources. This is because it has not been realized in practice due to obstacles such as difference of perception between society and government.

Conflicts between local communities-claiming their rights to land and forest resources and the forest industry with the government have consistently improved over the past few years [19,52]. Uncertainty of tenure and ownership of land for both society and industry contributes to land and forest degradation and, in many instances, causes violence. The heart of the matter is the uncertainty of the 'rules of the game' set by the Ministry of Forestry. 
This state institution claims its authority over much of Indonesia, but is unable to demonstrate its ability to manage such a vast territory and is unable to provide the necessary assurance of mastery and management both by the local community. The current paradigm chosen for managing the Forest Zone is an intensive use to foster economic development. Forest areas are categorized as timber production forests, areas designated for conversion to other uses, and conservation areas.

Legal chaos and uncertainty have had devastating effects on the living systems of rural communities who have traditionally lived dependent on forests for their livelihoods but have no legal right to forests. In the past, forest concessions for timber harvesting in vast quantities existed in community-affected areas. Similarly, since the mid-80s, the government has promoted plantations (plantations or oil palm plantations) 'alienating' forests without considering the rights of local communities.

This legal uncertainty causes large-scale deforestation caused by biodiversity depletion and in many places leads to soil erosion, sedimentation and destruction of forest hydrological functions, thus exacerbating food security and threatening potential future economic and environmental benefits of forests $[48,50]$. Economic reforms in the early $90 \mathrm{~s}$ shifted the production and enterprise bases from cooperative forms to individual ownership, such as forest land allocations for individuals or groups. This is very supportive of the economic development of the community, therefore it is necessary to understand the actors involved in development is very important, because the development process involves many parties that each has a role, there must be clarity of responsibility and authority roles [21].

Studies in Panama prove that effective tenure rights have reduced the rate of deforestation, in Nepal and Vietnam the increased quality of forest management occurs because of the transfer of rights to state forests to communities and individuals [33]. From the evidence presented it is clear that the context of the various countries is actually diverse and without doubt it is recognized that there are many factors that determine both the poor management of forests where land tenure assurance is one of the important factors. However, it is not difficult to imagine the above situation where the future net benefits of long-term forest management based on ownership of secured land can exceed the availability of resources, thus creating the necessary conditions and incentives for sustainable forest management to be realized in Indonesia.

\subsection{Shared Economics in Forest Management Policy}

The existence of the Jungle rubber in both private and state forest areas (GFP STS) proves that the status of the area will not affect the development of the Jungle rubber culture, as long as there is no economic option for the people to earn income in order to meet their life needs. The Jungle rubber as an environmentally friendly Rubber
(Hevea brasiliensis) commodity cultivation system that has a diversity similar to secondary forests, is able to maintain the water system (hydro-orology), improve soil structure and nutrients and absorb considerable carbon [14-15-36-54].

The Jungle rubber is a form of agricultural culture that uses a system of land preparation with shifting cultivation as a development of rice farming systems on highland lands. Shifting cultivation is the culmination of the subsistence culture of humans to transform into a commercial culture [48]. Traditional practices and technologies used by communities in Asian, African and Latin American countries to utilize forest resources are not the main cause of tropical forest destruction [45]. Shifting cultivation that local communities practice downhill is not a factor that encourages destruction, instead the mixed-mixed pattern practiced by the community is similar to the canopy structure in tropical forest ecosystems and this community-induced pattern does not cause a decline in the biodiversity richness of the tropical forests.

Threats to the security of tenure and community ownership of the land occur continuously from several strong pressures: forest concessions for timber, forest conversion from forest to plantation, transmigration projects and land occupation associated with clearing for timber or plantation harvesting by Groups of immigrants. None of those who possess that power and ability respect the rights of the people, but instead sweep people's opportunities for economic, welfare and tenure security [33].

New breakthroughs needed to integrate the Jungle rubber in forestry sector development with the justification that the Jungle rubber is a traditional biophysical-like form of secondary forest. To increase the economic value of Jungle rubber, it is necessary to develop/adopt agricultural technology by enriched with crops of economic value thereby increasing their resilience. This increase is done with the insertion of local superior plants and plant life so that it can increase its diversity. The integration of the Jungle rubber in forestry development will avoid the issue of frequent conflicts of interest in state forest areas with forest communities. Positive impacts that can be expected is the achievement of tropical forests that have a high diversity while supporting the life and welfare of people around the forest.

Ownership of land assets is a critical factor in the eradication of poverty. In many of the world 's poorest villages, forests are the main source of their livelihoods. Community empowerment-with legal ownership as an essential element is one of the most effective tools for reducing poverty and improving the conditions of rural communities:

"The assets that the poor have ... directly contribute to their well-being and have a tremendous impact on the opportunities to get out of poverty .... Expanding the assets of the poor can strengthen their economic, 
political and social positions and control over their own lives. Assets empower the poor. And assets help people manage risk (World Bank 2000) ".

Forests allow the poor to utilize their labor to gain productive benefits so that they are less dependent on wages and reduce their vulnerability to economic shocks. Land is the most important asset that the community can have. Much of the wealth of rural communities includes access and control over land. Securing land tenure and ownership rights implies a wealth transfer process and therefore contributes to empowerment and eradication of poverty in rural areas [33].

The following is the conclusion of a review of experiences in different countries. Empirical evidence from different regions of the world demonstrates the demand for greater tenure security and examples that provide the right intervention to increase tenure security provide real benefits both in terms of equity, investment, credit provision and cost reduction for Activities of supervision and protection of resource exploitation [34].

\subsection{Choice of Forest Management Institutions}

The government often expressed the importance of developing autonomous local decision making in natural resource management. However, laws that specifically regulate natural resources, especially forests, limit the space for the formulation of local decisions by requiring coordination with the central government or requiring coordination with the central government, in the absence of special mechanisms to do so.

In the case of GFP STS the main problem faced by the manager is the existence of land ownership by the community. Such ownership is socially valid and applies to local institutions. Attempts to exclude community lands in the GFP STS area are responded by either covert or overt resistance. This condition actually affects the impact of forest degradation. Based on the investigation in this study shows that the complex system of natural resources is increasingly damaged when there is state intervention in its management. The causes are commercialization, land degradation, population pressures, encroachment and disproportionate distribution of benefits on common pool resorted resources by some members of the community [43].

GFP STS is the government's effort to provide public goods in the form of forest. The reorganization of collective action in the context of appropriate and synergistic situations between efficient state organizations, markets and civil society will be able to provide public goods [42,53]. Institutional choice is one of the most likely approaches on the ground that people have the ability to adhere to the institutional rules governing them in utilizing shared natural resources [8].

In the case of GFP STS management where a conservative nature conservation forest paradigm is inappropriate to use. Such inaccuracies have implications for failure to implement. It is important to consider what kind of rules are appropriate for designing forest management systems. The creation of rules affecting the wider community needs to be considered on what conditions the rules are made and how to keep the community in compliance with the rules.

Correct institutional choice should be based on the rationality of the individual community how much benefit would be gained if institutional change was applied [10-11-47]. Accommodations at local institutions built by communities inherent in their culture will provide an opportunity for success on the adherence of the community to the rules of the institutional system. Choosing an institutional form should have a simple concept with a framework to facilitate individual choice and avoid misunderstandings caused by the influence of historical processes outside the community as resource users.

Eliminating the complexity of the ownership system by avoiding the occurrence of legal pluralism of ownership by accommodating the concept of ownership held by the community and the concept of natural resource management conducted by the community will have positive implications for the sustainability of natural resources. Institutions should contain rules that provide incentives, motivate and opportunities for rational choice of society according to cultural changes. The concept as described above can not be in the institutional accommodation of forest area management in the form of Forest Park. It takes a forest management institution that can delegate authority to communities to manage forests with clear title rights.

Referring to the results of a review of biodiversity, silviculture and participatory mapping were collected as evidence of the social and environmental benefits of the Krui system. The Minister of Forestry was asked to consider the Krui system as a special area and in January 1998, the minister established Krui as KDTI (Fores for special purpose area) of 29,000 ha. For the first time local people were allowed to collect the proceeds, both timber and non-timber forest products from state forest areas. They are also given full rights to manage forests with self-organizing community management structures. The ICRAF team draws on the experience of the Philippines with the ancestral domain certification system as the basis for the plan [30]. In the case of GFP STS management where a conservative nature conservation forest paradigm is inappropriate to use. Such inaccuracies have implications for failure to implement. It is important to consider what kind of rules are appropriate for designing forest management systems. The creation of rules affecting the wider community needs to be considered on what conditions the rules are made and how to keep the community in compliance with the rules.

Correct institutional choice should be based on the rationality of the individual community how much benefit 
would be gained if institutional change was applied [10,47]. Accommodations at local institutions built by communities inherent in their culture will provide an opportunity for success on the adherence of the community to the rules of the institutional system. Choosing an institutional form should have a simple concept with a framework to facilitate individual choice and avoid misunderstandings caused by the influence of historical processes outside the community as resource users.

Eliminating the complexity of the ownership system by avoiding the occurrence of legal pluralism of ownership by accommodating the concept of ownership held by the community and the concept of natural resource management conducted by the community will have positive implications for the sustainability of natural resources. Institutions should contain rules that provide incentives, motivate and opportunities for rational choice of society according to cultural changes.

The concept as described above can not be in the institutional accommodation of forest area management in the form of Great Forest Park. It takes a forest management institution that can delegate authority to communities to manage forests with clear title rights. Referring to the results of a review of biodiversity, silviculture and participatory mapping were collected as evidence of the social and environmental benefits of the Krui system. For the first time local people were allowed to collect the proceeds, both timber and non-timber forest products from state forest areas. They are also given full rights to manage forests with self-organizing community management structures. The ICRAF team draws on the experience of the Philippines with the ancestral domain certification system as the basis for the plan [30].

\section{Conclusions}

The development of the forestry sector through forest management policies must be able to adapt to the social-system conditions of forest communities. The concept of forestry development is done by using the ecological aspect (forest structure and diversity) as an academic reference and social-system aspect as a technical reference. The social-system aspect is reflected and manifested in the local institutions of society. Using the social-system aspect as a technical reference means that forest management is done by the local community with its institutional instruments. While the academic reference in the form of ecological aspects is used as an instrument of assessing and considering whether local institutional competence meets criteria appropriate to ecological values in environmental management in order to adapt them to their cultural core conditions.

The co-evolution of policy and social systems is a concept to understand its influence reciprocally, development policy will proceed well and succeed if there is an adaptation between the two. Understanding of the dynamics of co-evolutionary variables includes: how the level of community knowledge about forests and forestry includes how important the development of the forest itself is; What technology is controlled by society to support its life system; Any organization built by the community; How environmental changes occur to develop a support system for people's lives and what values are believed by society to regulate their behavior.

Policy adaptation is done by considering the above. The ecological aspect as an academic reference is applied by adjusting proportionately to what factors can be accommodated in terms of vegetation and diversity structures. Weaknesses in the implementation of policies and social systems are improved by programs adapted to social systems (mainly related to their cultural core), such as land and forest rehabilitation programs using commodities that support community economic systems and are favored by the community.

It is therefore necessary to consider the institutional options for the management of the area currently designated as GFP STS with other more compatible institutional systems that can accommodate the dynamics of local community institutions. Changes in the aspects of values, knowledge, organization and environment are important factors in the framework of adaptation of society to survive for it is needed the concept of development policy that can accommodate these changes so that development programs can be successful and run sustainably.

\section{Acknowledgements}

The authors would like to ekspress sincere gratitude to Ministry of Research, Technology and Higher Education of the Republic of Indonesia for it has provided funding for the study.

\section{REFERENCES}

[1] A. Agrawal, K. Gupta. Decentralization and Participation: The Governance of common pool resources in Nepal's Terai. World Development, Vol. 33, no. 7, 1101-1014, 2005.

[2] A. Gouyon, H. de Foresta, P. Levang. 1993. Does 'Jungle Rubber' Deserve Its Name? An Analysis of Rubber Agroforestry Systems in Southeastern Sumatra. Agroforestry System, Vo. 22, 181-206, 1993.

[3] A.E. Assogbadjo, R.G. Kakaï, F.G. Vodouhê, C.A.M.S Djagoun, J.T.C. Codjia, B. Sinsin. Biodiversity and socioeconomic factors supporting farmers' choice of wild edible trees in the agroforestry systems of Benin (West Africa), Forest Policy and Economics, Vol. 14, 41-49, 2012.

[4] A.L. Strauss, J. Corbin. Basics of qualitative research: Grounded theory procedures and Techniques. 2nd. Edition. 
Sage Publications, Newbury Park, CA, 1998.

[5] B.E. Robinson, M.B. Holland, T.N. Treves. Does secure land tenure save forests? A meta-analysis of the relationship between land tenure and tropical deforestation. Global Environment and Change, Vol. 29, 281-93, 2014.

[6] B.G. Glaser. Advances in the methodology of grounded theory. Sociology Press Mill Valley. CA, 1978.

[7] C.C. Gibson, D. Becker. The lack of institutional supply: Why a strong local community in Western Ecuador fails to protect its forest. In People and Forests: Communities, Institutions and Governance, editors. C Gibson, M McKean, E Ostrom. Cambridge MIT Press. Massachusett, 2000.

[8] D. Klooster. Institutional choice, community and struggle: A case study of forest co-management in Mexico. World Development, Vol. 28, no. 1, 1-20, 2000.

[9] D. Suharjito. 2013. Reformasi agraria di sektor kehutanan: mewujudkan pengelolaan hutan lestari, keadilan sosial dan kemakmuran bangsa. Di dalam (in), Kembali ke jalanl lurus. H. Kartodhiharjo, Jhamtani, editors. FORCI Development. Bogor, 2013.

[10] E. Ostrom. Governing the commons: The evolution of institution for collective actions. Cambridge University Press. New York, 1990.

[11] E. Ostrom. Understanding Institutional Diversity. Princeton University Press. Princeton, 2005.

[12] E. Wollenberg, A. Ingles. Incomes from the Forest. Methods for the development and conservation of forest products for local communities. Center for International Forestry Research. Bogor, 1998.

[13] G. Burrel, G. Morgan. 1979. Sociological paradigms and organizational analysis. Heinemann Educational Books, 1979.

[14] G. Michon G, H. de Foresta. The Indonesian agroforest model: Forest resource management and biodiversity conservation. In: P. Halladay, D.S. Gilmour, editors. Conserving biodiversity outside protected areas: The role of traditional agro-ecosystems. IUCN. Cambridge, 1995.

[15] G. Michon, H. de Foresta H. Agroforests: Incorporating a forest vision in agroforestry. In: L.E. Buck, J.P. Lassoie, E.C.M. Fernandes, Editors. Agroforestry in sustainable agricultural systems. Lewis Publishers. Boca Raton, 1999.

[16] G. Wibawa, D. Boutin, A.F.S. Budiman.alternatif pengembangan perkebunan karet rakyat dengan pola wanatani. Di dalam (in), B. Drajat, M. Supriyadi, A. Gunawan, U. Fadjar, C. Nancy, editors. Prosiding lokakarya dan ekspose teknologi perkebunan, 26-28, Oktober 1999. Palembang, 1999.

[17] G.M. Hodgson. Darwinian coevolution of organizations and the environment. Ecological Economics, Vol. 69, 700-706, 2010 .

[18] G.R. de Snoo, I. Herzon, H. Staats, R.J.F. Burton, S. Schindler. Toward effective nature conservation on farmland: Making farmers matter, Conservations Lett. 6:6672,2013

[19] H. Lynch. Sumberdaya milik siapa?; Siapa penguasa barang publik. Studio Kendil. Bogor, 2006.
[20] H.L. Wright, I.R Lake, P.M. Dolman. Agriculture-a key element for conservation in the developing, World Conservation Lett, Vol. 5, 11-19, 2012.

[21] J. Blackburn, J. Holland. Who change? Institutionalizing in development. Intermediate technology publications Ltd. London, 1998

[22] J. Caldwel. Desertification: Demographic evidence, 1973-83. Occasional paper no. 37, Australian National University. Melbourne, 1984.

[23] J. Kahn, J. McDonald. International Debt and Deforestation. In the Causes of tropical deforestation: The economic and statistical analysis of factors giving rise to the loss of the tropical forests. UBC Press. British Columbia. Vancouver, 1994.

[24] J. Ribot, N. Peluso N A theory of access. Rural Sociology, Vol. 68, 153-181, 2003.

[25] J.C. Allen, D.F. Barnes. The Causes of Deforestation in Developing Countries, Annuals of the Association of American Geographers, Vol. 75, no. 2, 163-184, 1985.

[26] J.C. Burgess. Economic Analysis of the causes of tropical deforestation. Discussion Paper No. 92-03. London Environmental Economics Centre. London, 1992.

[27] J.E.M. Arnold, P.A. Dewees. Tress management in farmer strategies, responses to agricultural intensification. Oxford University Press. Oxford, 1995.

[28] J.E.M. Arnold. Community Forestry: Ten Years in Review. FAO. Rome, 1992.

[29] J.H. Steward. Theory of cultural change: The methodology of multilinear evolution. University of Illinois Press, Urbana, 1955.

[30] J.P.C. Colfer, D.R. Dahal, D. Capistrano. Pelajaran dari desentralisasi kehutanan; mencari tata kelola yang baik dan berkeadilan di asia-pasifik. Badan Planologi Kehutanan, Departemen Kehutanan dan Center for International Forestry Research (CIFOR). Bogor, 2009.

[31] J.T. Thomson. A framework for analyzing institutional incentives in community forestry. FAO, Community Forestry Note No. 10. Rome. 1992.

[32] J.W. Creswell. Research design; Pendekatan kualitatif, kuantitatif dan mixed. Pustaka Pelajar. Yogyakarta, 2012

[33] K. Deininger, F. Xia, S. Savastano. Smallholders' land ownership and access in sub-saharan africa. A new landscape? A World Bank policy research working paper no. 7285. World Bank research support team, 2015.

[34] K. Deininger. Land policies for growth and poverty reduction. A World Bank policy research report no. 26384. Oxford University Press. Oxford, 2003.

[35] L. Capistrano, A. Doris. Tropical forest depletion and the changing macroeconomy, 1967-1985. In the causes of tropical deforestation, B. Katrina, D.W. Pearce, editors, 6885. UBC Press. Vancouver, 1994

[36] L. Joshi, G. Wibawa, G.Vincent, D. Boutin, R. Akiefnawati, G. Manurung, M.van Noordwijk. Complex rubber agroforestry: Challenge for development. Booklet TFRI extension series No. 139, 2002 
[37] M. Poffenberger, B. McGean. Village voices, forest choices: Joint forest management in India. Oxford University Press. New Delhi, 1998.

[38] M. Poffenberger. Keepers of the Forest: Land management alternatives in Southeast Asia. Kumarian Press. West Hartford, 1990.

[39] M. Tiffen M, M. Mortimore, F. Gichuki. More People, less erosion: Environmental recovery in Kenya. Wiley. New York, 1994

[40] M. Wolman. Population, land use and environment: a long history. In C. Jolly and B. Torrey, editors. Population and land use in developing countries. National Academy Press. Washington DC.

[41] N. Bazaara. Decentralization, politics and environment in Uganda. Environmental governance in Africa, Working paper series no 7. World Resources Institute. Washington, DC, 2003.

[42] N.T. Uphoff. Local Institutions and Participation for Sustainable Development. International Institute for Environment and Development (IIED). London, 1992.

[43] P. Blaikie, H. Brookfield. Land degradation and society. Methuen. London, 1987.

[44] P. Illukpitiya, J.F. Yanagida. Farming vs forests: Trade-off between agriculture and the extraction of non-timber forest products. Ecological. Economics, Vol. 69, no. 19, 52-63, 2010 .

[45] P. Robbin. Political ecology. John Wiley \& Sons Ltd. Arizona, 2012

[46] P.R. Ehrlich, A.H. Ehrlich. Healing the Planet: Strategies for resolving the environmental crisis. Reading Addison Wesley. Massachusett, 1991.

[47] R. Wade. Village republics: Economic conditions for collective action in South India. Cambridge University Press. Cambridge, 1988.

[48] R.B. Norgaard. Coevolutionary agricultural development. Economic development and cultural change, Vol. 32, no. 3, 525-546, 1984.

[49] R.B. Norgaard. Development betrayed; The end of progress and a coevolutionary revisioning of the future. Routledge 11 new fetter lane, London, 1994.

[50] R.B. Norgaard. Sociosystem and ecosystem coevolution in the Amazon. Environmental economics and management, Vol. 8, 238-254, 1981.

[51] T. Rudel. Population, development and tropical deforestation: A cross-national tudy. In the causes of tropical deforestation. K. Brown, D.W. Pearce, editors, 96-105. UBC Press. Vancouver, 1994.

[52] T. Sikor, C. Lund. Access and Property: A Question of Power and Authority. Institute of Social Studies. The Hague, 2009

[53] T.A. White, C.F. Runge. The emergence and evolution of collective action: lessons from watershed management in Haiti. World Development, 23 (10), 1683-1698, 1995

[54] T.M. Egan. Grounded theory research and theory building. SAGE Publications.2002.

[55] T.P. Tomich, H. de Foresta, R. Dennis, Q.M. Ketterings, D. Murdiyarso, C.A. Palm, F. Stolle, Suyanto, M van Noordwijk. Carbon offsets for conservation and development in Indonesia. American Journal of Alternative Agriculture, Vo.17, 125-137, 2002.

[56] V. Valencia, L.G. Barrios, P. West, E.J. Sterling, S Naeem. 2014. The role of coffee agroforestry in the conservation of tree diversity and community composition of native forests in a biosphere reserve. Agriculture Ecosystem and Environment, Vol.189, 154-163, 2014 